\section{Breaking the cycle of failure in combating corruption in Asian countries}

\author{
Jon S.T. Quah \\ National University of Singapore (retired), Singapore
}

Corruption in Asian countries

\begin{abstract}
Purpose - The purpose of this paper is to identify the five mistakes made by political leaders in Asian countries in combating corruption. These mistakes constitute the cycle of failure which must be broken for Asian countries to succeed in fighting corruption.

Design/methodology/approach - This paper is based on the comparative evaluation of the effectiveness of the anti-corruption measures adopted by various Asian countries.

Findings - The cycle of failure in combating corruption in Asian countries arises from their governments' reliance on corrupt political leaders and the police, and multiple anti-corruption agencies as attack dogs or paper tigers.

Originality/value - This paper would be of interest to those policymakers, anti-corruption practitioners, and scholars, who are concerned with enhancing the effectiveness of anti-corruption strategies in their countries by breaking the cycle of failure.
\end{abstract}

Abstract

Keywords Anti-corruption agencies, Hong Kong, India, the Philippines, Singapore, Taiwan

Paper type Research paper

\section{Introduction}

In their seminal article, Schlesinger and Heskett (1991, pp. 17-18) contend that many service companies in the United States "perpetuate a cycle of failure by tolerating high turnover and expecting employee dissatisfaction" which contributes to "continuing deterioration of service quality, managerial headaches, and long-term decreases in sales and profits." A similar cycle of failure afflicts the anti-corruption strategies in many Asian countries because their political leaders have not learnt from the mistakes they have made in fighting corruption and continue to maintain the status quo by perpetuating the same errors.

As corruption is a serious problem in many Asian countries it is not surprising that their governments have relied on many anti-corruption measures, including anti-corruption agencies (ACAs), to combat corruption during the past seven decades. However, with the exceptions of Singapore and Hong Kong, many Asian countries have lost the war on corruption because their political leaders continue making five mistakes in combating corruption. Consequently, to win the war on corruption these leaders must break the cycle of failure by not repeating these mistakes and implementing instead the best practices employed by Singapore and Hong Kong for minimising corruption (Quah, 2021, pp. 16-20).

However, before analysing the five mistakes, it is necessary to ascertain the perceived extent of public sector corruption in Asian countries by examining their performance on Transparency International's Corruption Perceptions Index (CPI) in 2020 and the World

(C) Jon S.T. Quah. Published in Public Administration and Policy. Published by Emerald Publishing Limited. This article is published under the Creative Commons Attribution (CC BY 4.0) license. Anyone may reproduce, distribute, translate and create derivative works of this article (for both commercial and non-commercial purposes), subject to full attribution to the original publication and authors. The full terms of this license may be seen at http://creativecommons.org/licences/by/4.0/legalcode

The author would like to thank Professors Leslie Holmes and David Jones for their constructive feedback on an earlier vision of this paper.

\section{HKPAA}

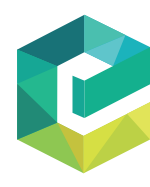

Public Administration and Policy Vol. 24 No. 2, 2021 Emerald Publishing Limite 1727-2645 DOI 10.1108/PAP-05-2021-0034 
PAP

24,2

126

Bank's Control of Corruption indicator in 2019. Table 1 shows that the CPI scores of the 27 Asian countries in 2020 range from 85 for Singapore, which is ranked third among 180 countries, to 16 for North Korea, which is ranked $170^{\text {th }}$. The average CPI score for these Asian countries is 42.7 with only eight countries having CPI scores exceeding 50 . Similarly, Table 1 also confirms that Singapore, Hong Kong SAR, Japan, Bhutan, Taiwan, South Korea, Brunei Darussalam and Malaysia are the eight Asian countries with the highest scores and percentile ranks for the Control of Corruption indicator in 2019.

\section{Mistake No. 1: Relying on corrupt political leaders to curb corruption}

In terms of fighting corruption, Rotberg (2009, p. 347) believes that leadership can alter corrupt behaviour when political leaders lead by example and enforce impartially a zero tolerance policy for corruption for all elected or appointed officials. Consequently, the first mistake occurs when countries rely on corrupt political leaders to minimise corruption because they "control and exploit everyone and everything for personal gain" and corruption enables them to claim as their own "the fruits of the nation's labor." More importantly, corrupt leaders transform the economy into "an instrument of leader wealth creation" and make

\begin{tabular}{|c|c|c|c|c|}
\hline \multicolumn{5}{|c|}{ Corruption Perceptions } \\
\hline \multicolumn{3}{|c|}{ Index } & \multicolumn{2}{|c|}{ Control of Corruption } \\
\hline Rank & Score ${ }^{a}$ & Country/Region ${ }^{\mathrm{b}}$ & Score & Percentile rank \\
\hline $3^{\text {rd }}$ & 85 & Singapore & 2.16 & 99.5 \\
\hline $11^{\text {th }}$ & 77 & Hong Kong SAR & 1.67 & 92.3 \\
\hline $19^{\text {th }}$ & 74 & Japan & 1.48 & 89.9 \\
\hline $24^{\text {th }}$ & 68 & Bhutan & 1.62 & 91.8 \\
\hline $28^{\text {th }}$ & 65 & Taiwan & 1.05 & 82.7 \\
\hline $33^{\text {rd }}$ & 61 & South Korea & 0.76 & 76.9 \\
\hline $35^{\text {th }}$ & 60 & Brunei Darussalam & 0.80 & 78.4 \\
\hline $57^{\text {th }}$ & 51 & Malaysia & 0.25 & 62.5 \\
\hline $75^{\text {th }}$ & 43 & Maldives & -0.26 & 46.2 \\
\hline $78^{\text {th }}$ & 42 & China & -0.32 & 43.3 \\
\hline $86^{\text {th }}$ & 40 & India & -0.23 & 47.6 \\
\hline $86^{\text {th }}$ & 40 & Timor-Leste & -0.38 & 41.3 \\
\hline $94^{\text {th }}$ & 38 & Sri Lanka & -0.32 & 44.2 \\
\hline $102^{\text {nd }}$ & 37 & Indonesia & -0.42 & 38.0 \\
\hline $104^{\text {th }}$ & 36 & Thailand & -0.41 & 39.4 \\
\hline $104^{\text {th }}$ & 36 & Vietnam & -0.51 & 34.1 \\
\hline $111^{\text {th }}$ & 35 & Mongolia & -0.44 & 37.5 \\
\hline $115^{\text {th }}$ & 34 & Philippines & -0.57 & 31.3 \\
\hline $117^{\text {th }}$ & 33 & Nepal & -0.67 & 27.4 \\
\hline $124^{\text {th }}$ & 31 & Pakistan & -0.85 & 21.2 \\
\hline $134^{\text {th }}$ & 29 & Lao PDR & -1.06 & 13.5 \\
\hline $137^{\text {th }}$ & 28 & Myanmar & -0.63 & 28.8 \\
\hline $142^{\text {nd }}$ & 27 & Papua New Guinea & -0.99 & 16.8 \\
\hline $146^{\text {th }}$ & 26 & Bangladesh & -0.99 & 16.3 \\
\hline $160^{\text {th }}$ & 21 & Cambodia & -1.30 & 9.6 \\
\hline $165^{\text {th }}$ & 19 & Afghanistan & -1.40 & 6.7 \\
\hline $170^{\text {th }}$ & 16 & North Korea & -1.59 & 2.9 \\
\hline \multicolumn{5}{|c|}{ Notes: ${ }^{\text {a }}$ The CPI score ranges from 0 (highly corrupt) to 100 (very clean). } \\
\hline \multicolumn{5}{|c|}{ For inclusion in the CPI, each country/region must have at least three independent surveys of corruption. 180} \\
\hline \multirow{2}{*}{\multicolumn{5}{|c|}{$\begin{array}{l}\text { countries/regions were included in the CPI in } 2020 \text { and } 215 \text { countries/regions were included in the World Bank's } \\
\text { Control of Corruption indicator in } 2019 .\end{array}$}} \\
\hline & & & & \\
\hline \multicolumn{5}{|c|}{ Sources: Transparency International (2021, pp. 2-3); World Bank (2020). } \\
\hline
\end{tabular}

Table 1.

Performance of 27 Asian countries/regions on the 2020 Corruption Perceptions Index and 2019 Control of Corruption indicator 
illegal or immoral practices like election fraud, torture or sexual assault acceptable (BenGhiat, 2020, pp. 12, 144).

To illustrate, among the 10 most corrupt political leaders identified by Transparency International in 2004, three were from Asia: President Mohamed Suharto of Indonesia (ranked first); President Ferdinand Marcos (ranked second) and President Joseph Estrada (ranked $10^{\text {th }}$ ) of the Philippines, as shown in Table 2. Corruption was institutionalised in Indonesia during Suharto's administration (1967-1998) and his family members benefited from their monopoly of the import, manufacture and distribution of many products. As corruption became deeply entrenched during Suharto's 31-year rule, his successors have found it difficult to minimise corruption. Corruption in contemporary Indonesia "has got worse, not better" because the "bureaucrats sense that the game is up and this is the last chance for them to gouge all the money they can out of the system" (Loveard, 1999, p. 378).

President Ferdinand Marcos' declaration of martial law on 22 September 1972 resulted in nearly 13 years of authoritarian rule and an exponential increase in corruption. President Marcos, his relatives, and cronies perpetrated the "politics of plunder" by treating "the Philippine treasury as if it were their personal checking account." The large international loans and U.S. foreign assistance packages meant for economic development provided easy opportunities for massive graft by Marcos and his cronies. Consequently, the Philippines lost billions of dollars and became the "basket case of Asia" by the late 1970s (Aquino, 1999, pp. 120-121).

Marcos died in exile in Honolulu on 28 September 1989 and was not punished at all for plundering his country's wealth. In March 2008, the 17-year trial of Imelda Marcos ended with her acquittal on 32 charges of illegally transferring wealth out of the Philippines (CBCNews, 2008). President Estrada was found guilty of receiving payoffs and kickbacks and sentenced to the maximum term of 40 years' imprisonment on 11 September 2007. However, President Gloria Macapagal-Arroyo pardoned Estrada on 25 October 2007 even though anti-corruption advocates and state prosecutors had advised her not to do so (Quah, 2011, p. 148). The South China Morning Post (2007, p. 14) criticised Arroyo for undermining the rule of law and sending the wrong message to officials that "graft and corruption are not serious crimes". Hence, it is not surprising that many Filipinos did not want her to remain in office. A national Pulse Asia survey conducted in October 2007 found that 42 per cent of the respondents believed that President Arroyo was the most corrupt president, followed by Marcos (35 per cent), Estrada (16 per cent), Ramos (5 per cent), and Aquino (1 per cent), as shown in Table 3.

\begin{tabular}{lll}
\hline Political leader & Position & Estimates of embezzled funds \\
\hline Mohamed Suharto & President of Indonesia, 1967-98 & US\$ 15 - 35 billion \\
Ferdinand Marcos & President of Philippines, 1972-86 & US\$ 5 - 10 billion \\
Joseph Estrada & President of Philippines, 1998-2001 & US $\$ 70-80$ million \\
Source: Hodess (2004, p. 13, Box 1.1). &
\end{tabular}

Corruption in Asian countries
Gloria Macapagal-Arroyo

Ferdinand E. Marcos

Joseph E. Estrada

Fidel V. Ramos

Corazon C. Aquino

Source: GMA News. TV (2007).

$$
\begin{array}{r}
42 \% \\
35 \% \\
16 \% \\
5 \% \\
1 \%
\end{array}
$$

Table 2

Estimates of Embezzled Funds by Three Asian Political Leaders 
PAP

24,2

In Taiwan, even though Chen Shui-bian campaigned on an anti-corruption platform in the 2000 presidential election, he and his immediate family succumbed to corruption during his two terms of office as president. After losing his immunity from prosecution on leaving office in May 2008, Chen was accused of embezzlement, bribery, and money laundering. He was sentenced initially to life imprisonment and fined NT $\$ 200$ million (US\$6.1 million) by the Taipei District Court on 11 September 2009. However, the Taiwan High Court finally decided on 6 December 2010 to reduce Chen's term of imprisonment to 17.5 years with a fine of NT $\$ 154$ million (US $\$ 5.05$ million) because the amount embezzled was less than previously found by a lower court (Quah, 2011, pp. 153-155).

Malaysia was afflicted recently by the 1Malaysia Development Berhad (1MDB) scandal, which was described as "the world's biggest financial scandal" and "largest kleptocracy case" in American history because the United States Department of Justice believed that more than US $\$ 4.5$ billion was stolen from 1MDB (Ramesh, 2016). The Wall Street Journal reported on 2 July 2015 that Prime Minister Najib Razak had received US\$681 million in his private bank accounts in March 2013 (Wright and Hope, 2019, pp. 341-342). Najib covered up the 1MDB scandal by removing from office the Deputy Prime Minister, four ministers, the AttorneyGeneral, and some junior officials during 2015-2016 to prevent them from exposing evidence of corruption. Jones (2020, p. 67) contends that the most important reason for the $1 \mathrm{MDB}$ scandal was Najib's lack of political will because, as the prime minister and chairman of the $1 \mathrm{MDB}$ advisory board, he was also a beneficiary of the embezzlement. Indeed, Najib had blatantly used the 1MDB funds to feather his kleptocratic interests.

After Najib's government lost the May 2018 general election in Malaysia, the new Pakatan Harapan government initiated investigations into the $1 \mathrm{MDB}$ scandal. The police raided the Najib family's apartments on 16-17 May 2018 in Kuala Lumpur and confiscated US $\$ 274$ million worth of luxury items, including 567 handbags, 423 watches, 12,000 pieces of jewellery and US\$28 million in cash (Wright and Hope, 2019, p. 406). The Malaysian AntiCorruption Commission (MACC) officers arrested Najib on 3 July and his wife on 3 October 2018. Najib's trial began in April 2019 and he was found guilty of seven charges of abuse of power, money laundering and criminal breach of trust and sentenced to 12 years' imprisonment and fined RM\$210 million (US\$49.38 million) on 28 July 2020 (Kanyakumari, 2020). He has filed an appeal and is out on bail until the appeal is completed.

In South Korea, Lee Myung-bak, who served as president from 2008 to 2013, was first convicted in late 2018 for embezzling 25.2 billion won (US $\$ 22.3$ million) and accepting 9.4 billion won (US\$8.3 million) in bribes. The Supreme Court upheld Lee's conviction and 17 year jail term in November 2020. Lee's imprisonment means that all four of South Korea's living former presidents are either imprisoned or have served jail terms on corruption charges (Straits Times, 2020). Park Geun-hye, who was president from 2013 to 2017, was sentenced to 24 years' imprisonment in April 2018 for corruption and abuse of power (BBC News, 2018). Former President Chun Doo-hwan was sentenced by the Seoul District Court in August 1996 to death for mutiny, treason and corruption. His successor, former President Roh Tae-woo, was sentenced to 22.5 years imprisonment on similar charges. However, in December 1997, President Kim Young-sam granted amnesty to Chun and Roh after they had been imprisoned for 16 months (Quah, 2011 p. 324).

As leopards cannot change their spots, it is unrealistic to expect corrupt political leaders to behave honestly and govern in the best interests of their citizens and countries. The above examples of the serious damage inflicted on Indonesia, the Philippines, Taiwan, Malaysia and South Korea by their corrupt political leaders confirm the importance of electing competent and honest leaders for political office to minimise corruption in these five countries. Unfortunately, democratic elections in these countries have failed to produce honest political leaders with strong political will to curb corruption. According to K. Shanmugam, Singapore's Minister for Home Affairs and Law, the "real key" to combating corruption is 
"unflinching determination at the top" because "you can have the best rules, the best anticorruption agency, but if your politicians are corrupt ... nothing is going to save the system" (quoted in Tepperman, 2016, pp. 117-118).

However, this first mistake is difficult to eradicate in many Asian countries because of the lack of political will and capacity and the criminalisation of politics that enables criminals to compete in elections. For example, 120 (22 per cent) of the 543 Members of Parliament (MPs) elected in 2004 in India had criminal cases involving murder, robbery and rape against them (Chishti, 2009, p. xv). Similarly, 37.8 per cent of town representatives in Taiwan in 1995 had organised crime backgrounds, followed by 26.5 per cent of county and city councillors, and 3 per cent of the national representatives (Quah, 2011, p. 169).

\section{Mistake No. 2: Relying on corrupt police to curb corruption}

The second mistake of relying on the corrupt police to curb corruption was made by the British colonial government in its colonies, including Singapore, Hong Kong and India, to mention three examples. Ignoring the "golden rule" of not allowing the police to investigate their "own deviance and crimes" (Punch, 2009, p. 245), the British colonial government in Singapore enacted the Prevention of Corruption Ordinance in December 1937, which made the Anti-Corruption Branch (ACB) of the Criminal Investigation Department of the Singapore Police Force (SPF) responsible for curbing corruption even though the 1879 and 1886 Commissions of Inquiry found that police corruption was rampant in the SPF (Quah, 2011, pp. 216-217).

The British colonial government ignored the findings of both Commissions when it entrusted the $\mathrm{ACB}$ with the function of combating corruption. The folly of this decision was exposed by the Opium Hijacking scandal on 27 October 1951, which involved the robbery of 1,800 pounds of opium worth $\mathbf{S} \$ 400,000$ (US\$133,333) by three police detectives. This triggering event revealed the ACB's ineffectiveness and resulted in the establishment of the Corrupt Practices Investigation Bureau (CPIB) in Singapore in September 1952 (Quah, 2011, p. 209).

The same pattern of corruption control was also observed in Hong Kong when the British colonial government made the ACB responsible for curbing corruption in 1948 even though there was widespread police corruption. The ACB was upgraded into the Anti-Corruption Office in May 1971 but its inability to minimise police corruption was revealed when a corruption suspect, Chief Superintendent of Police, Peter S. Godber, escaped to Britain on 8 June 1973 to avoid arrest. The resulting public outcry forced Governor Murray MacLehose to establish the Independent Commission Against Corruption (ICAC) in February 1974 (Quah, 2011, pp. 251-253).

Singapore and Hong Kong have succeeded in combating corruption by rejecting the British colonial government's method of relying on the police for corruption control and relying instead on independent ACAs like the CPIB and ICAC, respectively. This breakthrough in combating corruption was made by Singapore after 15 years (1937-1952) and by Hong Kong after 26 years (1948-1974) (Quah, 2011, pp. 104-105). Unlike Singapore and Hong Kong, India has not learnt this important lesson for the past 58 years because it still relies on the Central Bureau of Investigation (CBI), which was formed in April 1963 as part of the police, and is the lead ACA.

The CBI is a Type B ACA that performs many functions, including combating public sector corruption, curbing economic and violent crimes, fighting cyber and high technology crime, and combating national and transnational organised crime (CBI, 2010, p. iv). However, the CBI's ineffectiveness is reflected in India's $86^{\text {th }}$ ranking among 180 countries with a score of 40 on the CPI in 2020 (see Table 1). The CBI is ineffective for two reasons. First, as a police agency, it is hindered by the conflict of interest in curbing the rampant police corruption in 
PAP

24,2

130

India. Second, the CBI is a paper tiger because it is under-staffed and poorly funded to perform its various functions effectively. The CBI's establishment has increased from 5,886 personnel in 2003 to 7,274 personnel in 2015, but its actual strength varies from 4,623 personnel in 2007 to 5,796 personnel in 2013. This means that the number of vacancies in the CBI has increased from 719 (12.2 per cent) in 2009 to 1,693 (23.3 per cent) in 2015. Arising from the CBI's chronic staff shortage, it has an unfavourable staff-population ratio, which ranges from 1:234,217 in 2005 to 1:228,206 in 2014 (Quah, 2017, pp. 52-53).

In sum, India can only succeed in minimising corruption if it learns from the experiences of Singapore and Hong Kong and replaces the CBI with a new Type A ACA that is independent of the police to avoid the conflict of interest in dealing with police corruption cases and be responsible only for performing anti-corruption functions.

\section{Mistake No. 3: Relying on many ACAs - "Too many cooks spoil the broth"}

An ACA is a specialised agency created by a government to minimise corruption in a country. The effectiveness of Singapore's CPIB and Hong Kong's ICAC in combating corruption has resulted in the proliferation of many ACAs in Asian countries. Even though 17 Asian countries have relied on single ACAs like Singapore and Hong Kong, Table 4 shows that seven Asian countries have relied on many ACAs to curb corruption.

Among the seven Asian countries, the Philippines, which currently has five ACAs, holds the record for establishing 21 ACAs during the past 71 years, as shown in Table 5 . The proliferation of ACAs in the Philippines is the result of the frequent changes in political leadership because these ACAs are either created or abolished by the incoming president. From May 1950 to January 1966, five ACAs were formed and dissolved with the five changes in political leadership during that period. Similarly, President Marcos established another

\begin{tabular}{ll}
\hline Country/Region & Anti-Corruption Agencies \\
\hline Afghanistan & High Council of Governance, Rule of Law and Anti-Corruption \\
& High Office of Oversight and Anti-Corruption \\
& Anti-Corruption Justice Centre \\
& Civilian Anti-Corruption Prosecution Departments \\
& Military Anti-Corruption Prosecution Departments \\
& National Supervisory Commission \\
China & Central Commission for Discipline Inspection \\
& Supreme People's Procuratorate \\
& National Corruption Prevention Bureau \\
& Central Bureau of Investigation \\
India & Central Vigilance Commission \\
& Anti-Corruption Bureaus and State Vigilance Commissions in 28 States \\
Pakistan & National Accountability Bureau and Regional Offices \\
Philippines & Federal Investigation Authority \\
& Office of the Ombudsman, Special Anti-Graft Court \\
& Inter-Agency Anti-Graft Coordinating Council \\
Tresidential Commission on Good Government & Office of the Deputy Secretary for Legal Affairs \\
Taiwan & Ministry of Justice Investigation Bureau \\
Vietnam & Agency Against Corruption \\
& Central Steering Committee for Anti-Corruption \\
Gource: Compiled by the author. & People's Procuracy \\
\end{tabular}

Table 4.

Reliance on many ACAs by seven Asian countries/regions
Source: Compiled by the author. 


\begin{tabular}{|c|c|c|c|}
\hline Anti-Corruption Agency & President & Period & $\begin{array}{r}\text { Corruption in } \\
\text { A sian }\end{array}$ \\
\hline Integrity Board & Quirino & May - November 1950 & countries \\
\hline Presidential Complaints and Action Committee & Magsaysay & December 1953 - July 1958 & \\
\hline Presidential Committee on Administrative & Garcia & July 1958 - December 1961 & \\
\hline \multicolumn{4}{|l|}{ Performance Efficiency } \\
\hline Presidential Anti-Graft Committee & Garcia & $\begin{array}{l}\text { February } 1960 \text { - December } \\
1961\end{array}$ & 131 \\
\hline \multicolumn{4}{|l|}{ Presidential Anti-Graft Committee } \\
\hline $\begin{array}{l}\text { Presidential Agency on Reforms and Government } \\
\text { Operations }\end{array}$ & Marcos & January - September 1966 & \\
\hline Presidential Complaints and Action Office & Marcos & September 1966 - October 1967 & \\
\hline \multicolumn{3}{|l|}{ Operations } & \\
\hline Complaints and Investigations Office & Marcos & February 1970 - February 1986 & \\
\hline Special Cabinet Committee in Backsliding & Marcos & October 1973 - February 1986 & \\
\hline \multirow{2}{*}{ Office of the Ombudsman } & Marcos & July 1979 - April 1988 & \\
\hline & Aquino & May 1988 - present & \\
\hline Sandiganbayan (Special Anti-Graft Court) & Marcos & July 1979 - present & \\
\hline Presidential Commission on Good Government & Aquino & February 1986 - present & \\
\hline Presidential Committee on Ethics and Accountability & Aquino & February 1986 - May 1988 & \\
\hline Presidential Commission Against Graft and Corruption & Ramos & February 1994 - June 2000 & \\
\hline Inter-Agency Anti-Graft Coordinating Council & Estrada & August 1999 - present & \\
\hline Presidential Committee on Effective Governance & Estrada & October 1999 - April 2001 & \\
\hline National Anti-Corruption Commission & Estrada & July 2000 - April 2001 & \\
\hline Presidential Anti-Graft Commission & Arroyo & April 2001- November 2010 & \\
\hline Governance Advisory Council & Arroyo & July 2001 - June 2010 & Presidential ACAs in \\
\hline Office of the Deputy Secretary for Legal Affairs & Arroyo & November 2010 - present & the Philippines, \\
\hline \multicolumn{3}{|c|}{ Sources: Batalla (2001, p. 47; 2015, pp. 55-58) and Oyamada (2005, pp. 100-101). } & 1950 - present \\
\hline
\end{tabular}

five ACAs during his 21 years in power because the first three ACAs were ineffective and lasted between eight months and two years (Quah, 1982, pp. 168-169).

The reliance on multiple ACAs has not benefited the Philippines because the proliferation of ACAs has resulted in "duplication, layering and turf wars" (Quimson, 2006, p. 30). Apart from "passing the buck" instead of taking responsibility, there is also no coordination or cooperation among the ACAs, which compete for recognition, personnel and resources because they are under-staffed and poorly funded. These ACAs have overlapping jurisdiction, which diffuses anti-corruption efforts and results in "poor coordination in policy and programme implementation, weak management and wastage of resources" (Oyamada, 2005, p. 99).

Not surprisingly, Co et al. (2007, p. 21) have correctly questioned the formation of new ACAs by a new administration without evaluating the effectiveness of the existing ACAs thus:

\footnotetext{
Each administration created flagship programs and projects, sending the message that the political leadership was doing something against graft and corruption. However, the creation of such commissions and bodies may have been redundant and costly for the government. Although this may not be an efficient way of doing things ... the creation of these bodies ... should be examined to ascertain whether or not they contribute to the commission of corruption in the public administrative system. An attendant question one could raise is why a new program needs to be created each time a new administration steps in instead of merely building on past efforts.
}

In short, political leaders in the Philippines will fail in combating corruption if they do not replace this third mistake of relying on ineffective multiple, overlapping, uncoordinated, poorly staffed, and under-funded ACAs with the establishment of a single independent, 
powerful and adequately funded and staffed Type A ACA like the CPIB in Singapore or the ICAC in Hong Kong.

\section{Mistake No. 4: Using the ACA as an attack dog against political opponents}

The fourth mistake occurs when a political leader succumbs to the temptation of misusing an existing ACA or creating a new ACA as an attack dog against his or her political opponents instead of fulfilling its primary objective of minimising corruption in the country. This mistake is committed by corrupt political leaders who use ACAs as attack dogs to conduct "witch hunts" to eliminate opposition political party members or punish their own party members who have stepped out of line (Meagher and Voland, 2006, p. 6). Political leaders in many Asian countries have used their ACAs as attack dogs. However, space constraints permit only the analysis of the well-known examples of the Bureau for Anti-Corruption (BAC) and the Anti-Corruption Commission (ACC) in Bangladesh, the CBI in India, and the National Accountability Bureau (NAB) in Pakistan below.

The BAC was originally established by the enactment of the Anti-Corruption Act in 1957 in East Pakistan. It was reorganised and focused on combating corruption after Bangladesh attained independence in March 1971. The BAC was ineffective because it was "riddled with corruption" (Alim, 2005, p. 104). Its Achilles' heel was its "political face" as it was used by the incumbent government as "a political tool to harass the opposition" (Ahmed, 2006, p. 27). Nearly 200 corruption charges were filed against political leaders and MPs from 1991-2004. After assuming power, the ruling Bangladesh National Party (BNP) government (2001-2006) withdrew the 69 corruption cases filed by the BAC against its ministers, MPs and leaders during the Awami League (AL) government of 1996-2001. In December 2001, the BAC filed corruption charges against former Prime Minister Sheik Hasina and six officials for misappropriating US\$120.69 million in the purchase of eight MIG-29 jet fighter planes from Russia (Ahmed, 2006, p. 27). Thus, the "standard practice" of the ruling party, whether AL or $\mathrm{BNP}$, is to use the BAC to lodge complaints against the previous government, which means that the ruling party is "always immune from prosecution as long as they remain in power" (Ahmed, 2006, p. 28). The BAC was accused of engaging in "political witch-hunts" because it only investigated corruption cases after getting approval from the prime minister's office (Shah, 2001, p. 44).

The BAC was replaced by the ACC on 21 November 2004 with the enactment of the AntiCorruption Commission Act of 2004. Unfortunately, the ACC has not learnt from the BAC's mistakes for two reasons. The most important reason was that the ACC was established in 2004 in response to pressure from foreign donors and civil society representatives and not because of the BNP government's commitment to curbing corruption in Bangladesh. The BNP government decided to establish the ACC "reluctantly, rather than out of genuine political will" in response to "a combination of civil society demands and pressure from international donors" (Zaman et al., 2006, p. 127). The second reason was the ACC's unwise decision to rehire many of the BAC's ineffective personnel, including those who were accused of corruption. Consequently, the ACC inherited the BAC's baggage "when it sweepingly absorbed its staff without due scrutiny, and therefore sowed the seeds of [the] ACC's deficit of efficiency and integrity" (Iftekharuzzaman, 2019) and also the BAC's 20,000 unsolved cases (Begum and Sakib, 2010, p. 254).

As mentioned above, the CBI is a paper tiger because it is under-staffed and poorly funded to perform its functions. The CBI holds the distinction of being the only Asian Type B ACA that functions as both an attack dog and a paper tiger. The CBI is an attack dog because it has been perceived by the public as "a pliable tool of the ruling [Congress] party and its investigations tend to become cover-up operations for the misdeeds of ministers" (Gill, 1998, p. 238). More recently, the former Central Vigilance Commissioner, N. Vittal (2012, pp. 132-134), 
criticised the $\mathrm{CBI}$ for lacking independence and credibility because it has become "a football between the party in power and the party in opposition" as the cases initiated by one regime are neutralised by the next.

In the same vein, the CBI was criticised harshly by a Supreme Court Justice, R.M. Lodha, in May 2013 for being a "caged parrot" and "its master's voice". He scolded the attorney-general for interfering in the CBI's investigation of the "Coalgate" scandal involving alleged irregularities in the allocation of coalfield licences to private companies (Colvin and Bhattacharya, 2013). Finally, the late Joginder Singh (1999, p. 301) who was the CBI Director from July 1996 to June 1997, wrote in his memoirs that "nothing ails the CBI except that the top people would like to use the investigations to settle their own score." He revealed that he was transferred from his position as the CBI Director after 11 months for resisting the pressure exerted by the then Prime Minister I.K. Gujral in the fodder scam case (Singh, 1999, pp. 141, 302). In other words, the CBI has been used by many governments in India as an attack dog against their political opponents.

Governments in Pakistan have formulated anti-corruption laws but it is the political goal of eliminating opposition that has prompted such legislation and subsequent trials for corruption. During the administration of Zia-ul-Haq (1977-1988), politicians from the Pakistan People's Party (PPP) were put on trial. After 1988, the PPP and Pakistan Muslim League were "engaged in a game of musical chairs in terms of charging the opposition for corruption." Consequently, the "condemnation of an outgoing government on charges of corruption" became "a typical source of legitimacy" for the new government after General Ayub Khan assumed power through a military coup in 1958 (Waseem, 2002, p. 159).

Following the October 1999 military coup led by General Pervez Musharraf, the NAB was established to curb corruption and enhance the accountability of politicians and officials in Pakistan for their actions. However, in reality, the NAB has targeted politicians and civil servants from previous civilian governments and discredited political opponents and junior government officials (Chêne, 2008, p. 8). The NAB was used as a political tool to erode the military's opposition by transferring the authority of the Federal Investigation Authority to investigate corruption even though it was better equipped to do so (Crisis Group, 2010, pp. 4-5). According to Transparency International Pakistan (TIP), the NAB lacks operational autonomy because of the government's reliance on it as a weapon against political opponents. The National Accountability Ordinance of 1999 provides the NAB with operational powers and independence, but in practice, it is not immune from political pressures and has been accused of "being a partisan agency used for political victimisation by the government" (TIP, 2014, pp. 159-160, 166). Furthermore, the stakeholders interviewed by TIP have admitted that political interference has eroded the NAB's impartiality and its victimisation of political opponents is also confirmed by them and media reports (TIP, 2017, p. 38).

\section{Mistake No. 5: Establishing the ACA as a paper tiger to ensure its failure}

The fifth mistake of relying on the ACA as a paper tiger without the required powers and resources reflects the weak political will of a government that is unconcerned with minimising corruption in the country. This mistake usually occurs when the government is compelled by a corruption scandal or pressure from an international donor agency to establish a weak ACA with limited legal powers and inadequate resources as "window dressing" to demonstrate its commitment to combating corruption. ACAs which are paper tigers also lack the capacity to process digital flows of money and identify shell companies as shown in the MACC's limitations in investigating the 1MDB scandal (Jones, 2020, pp. 68-69).

The reliance on the Office of the Ombudsman (OMB) in the Philippines, the AntiCorruption and Civil Rights Commission (ACRC) in South Korea, and the Agency Against Corruption (AAC) in Taiwan, as paper tigers in the three countries is analysed below.
Corruption in Asian countries 
PAP

24,2

The $\mathrm{OMB}$ is the lead ACA in the Philippines but it is a paper tiger because it is severely under-staffed and poorly funded even though its budget has increased from US $\$ 12$ million in 2005 to US $\$ 38.8$ million in 2014 and its personnel has grown from 957 to 1,214 during the same period. The OMB's staff-population ratio has varied from 1:79,883 in 2011 to 1:89,076 in 2008 and its per capita expenditure has increased from US\$0.15 to US\$0.39 during 2005-2014 (Quah, 2017, p. 58). Former Ombudsman Simeon Marcello lamented that the OMB was "designed to fail because of its crippling lack of resources." His comparison of the resources of the OMB with Hong Kong's ICAC in 2004 shows that the OMB's field investigatorbureaucracy ratio of 1:17,045 compares unfavourably with the ICAC's ratio of 1:208. The ICAC's per capita expenditure of US $\$ 12.43$ has also exceeded the OMB's per capita expenditure of US $\$ 0.10$ by 116 times (Marcelo, 2005, pp. 1,3). The OMB had 980 vacancies in 2014 as its 1,214 personnel constituted only 55.3 per cent of its established strength of 2,194 positions (OMB, 2015, p. 35).

South Korea is also ineffective in combating corruption because of its reliance on the Korea Independent Commission Against Corruption (KICAC) and its successor, the ACRC. Both ACAs are paper tigers because of their inability to investigate corruption cases and their limited resources. President Kim Dae-jung established the KICAC in January 2002 as a weak replica of Hong Kong's ICAC without investigative powers because the original draft legislation was strongly opposed by the National Assembly, the Public Prosecutor's Office and the National Police Agency as the two latter agencies wanted to perform the anticorruption function themselves (Quah, 2011, p. 330). The KICAC was a paper tiger that focused on corruption prevention in the public sector instead of investigating corruption cases.

The KICAC's anti-corruption functions were further diluted by President Lee Myung-bak in February 2008 when he merged the KICAC with the Ombudsman and the Administrative Appeals Commission to form the ACRC, ostensibly, to enhance their effectiveness. In reality, the ACRC's creation has blurred its anti-corruption role and accorded lower priority to this objective. More importantly, President Lee's weak political will in curbing corruption is reflected in the marginal increase in the ACRC's per capita expenditure from US $\$ 0.97$ to US\$1.15 during 2008-2014 and its highly unfavourable staff-population of 1:108,430 in 2014 (Quah, 2017, p. 37). The ACRC's ineffectiveness is reflected in South Korea's $33^{\text {rd }}$ ranking among 180 countries with a score of 61 on the CPI in 2020 (see Table 1).

The Ministry of Justice Investigation Bureau (MJIB) is the lead ACA in Taiwan, but it is a Type B ACA and a law enforcement agency responsible for the protection of national security and the investigation of these crimes: public corruption, malfeasance, and election fraud; economic crime; drug crime; money laundering; and cybercrime. The MJIB is a national security agency because the investigation of corruption, bribery, and vote-buying constitutes only one of its nine functions (Quah, 2011, p. 183). The AAC was established in July 2011 in Taiwan by President Ma Jing-jeou in response to the corruption scandal involving three high court judges and a district prosecutor in July 2010. Ma's decision to create the AAC was to appease public anger over the judicial scandal. However, his decision exacerbated the problem by creating rivalry between the AAC and the MJIB, which had opposed the AAC's formation.

Unlike the MJIB, the AAC is a Type A ACA responsible for formulating corruption-control policies, anti-corruption education, corruption prevention, and investigating corruption cases in Taiwan. But the AAC has not realised its potential as an effective Type A ACA from its inception in July 2011 because it was created as a paper tiger without sufficient budget and personnel to perform its functions effectively. Corruption remains a chronic problem in Taiwan as its CPI scores have fluctuated between 61 and 65 from 2012 to 2020 . Taiwan's anticorruption strategy is irrational because the MJIB has been given a larger budget and more personnel than the AAC to combat corruption even though the former is the national security 
agency and a Type B ACA. The MJIB's budget of US $\$ 182.9$ million was nearly 13 times larger than the AAC's budget of US $\$ 14.2$ million in 2017. Similarly, the MJIB had 2,339 personnel or almost 11 times more than the AAC's 214 personnel in 2017. Thus, the rational solution to Taiwan's impasse in curbing corruption is to change the AAC's status as a paper tiger by making it the only Type A ACA and providing it with the required resources to enable it to perform effectively as an independent watchdog (Quah, 2020).

\section{Conclusion: Breaking the cycle of failure}

Table 6 summarises the preceding analysis by comparing the 2014 per capita expenditures, staff-population ratios, and roles of eight ACAs and their countries' CPI scores in 2020. It confirms that the CPIB and ICAC are independent watchdogs and the most effective ACAs in combating corruption as reflected in Singapore's and Hong Kong's CPI scores in 2020. Table 6 also shows that South Korea's ACRC, Taiwan's AAC and Philippines' OMB are paper tigers and less effective than the CPIB and ICAC. Finally, Bangladesh, India and Pakistan have also failed to curb corruption because of their reliance on the ACC, CBI and NAB, respectively, as attack dogs against political opponents. Among the eight ACAs in Table 6, India's CBI is unique because it functions as both a paper tiger and an attack dog.

To break the cycle of failure which has characterised the anti-corruption efforts in many Asian countries for the past 70 years, the political leaders must first recognise that as they are responsible for making the five mistakes in the first place, they also hold the key to ensure that these mistakes are not repeated. Needless to say, the task of breaking this cycle of failure is extremely challenging and requires not only a strong dose of political will and capacity to minimise corruption, which is currently lacking in many Asian countries, but also tremendous public support for a policy of zero tolerance for corruption to succeed.

Nevertheless, the success stories of Singapore and Hong Kong in combating corruption give hope to other Asian countries and demonstrate that honest political leaders who are committed to curbing corruption can break the cycle of failure by relying on the CPIB and ICAC, respectively, to enforce the anti-corruption laws impartially as independent watchdogs
Corruption in Asian countries

\begin{tabular}{|c|c|c|c|c|}
\hline $\begin{array}{l}\text { Anti- } \\
\text { Corruption } \\
\text { Agency }\end{array}$ & $\begin{array}{l}2014 \text { Per capita } \\
\text { expenditure }\end{array}$ & $\begin{array}{c}2014 \text { Staff- } \\
\text { population ratio }\end{array}$ & $\begin{array}{l}\text { Role of Anti-Corruption } \\
\text { Agency }\end{array}$ & $\begin{array}{c}2020 \text { CPI rank \& } \\
\text { score }\end{array}$ \\
\hline $\begin{array}{l}\text { ICAC (Type A) } \\
\text { Hong Kong }\end{array}$ & US $\$ 16.59$ & $1: 5,333$ & Independent watchdog & $11^{\text {th }}(77)$ \\
\hline $\begin{array}{l}\text { CPIB (Type A) } \\
\text { Singapore }\end{array}$ & US\$5.36 & $1: 26,682$ & Independent watchdog & $3^{\text {rd }}(85)$ \\
\hline $\begin{array}{l}\text { ACRC (Type B) } \\
\text { South Korea }\end{array}$ & US $\$ 1.15$ & $1: 108,430$ & Paper tiger & $33^{\text {rd }}(61)$ \\
\hline $\begin{array}{l}\text { AAC (Type A) } \\
\text { Taiwan }\end{array}$ & US\$0.61 & $1: 97,641$ & Paper tiger & $28^{\text {th }}(65)$ \\
\hline $\begin{array}{l}\text { OMB (Type B) } \\
\text { Philippines }\end{array}$ & US\$0.39 & $1: 81,631$ & Paper tiger & $115^{\text {th }}(34)$ \\
\hline $\begin{array}{l}\text { CBI (Type B) } \\
\text { India }\end{array}$ & US\$0.05 & $1: 228,206$ & $\begin{array}{l}\text { Paper tiger and attack } \\
\text { dog }\end{array}$ & $86^{\text {th }}(40)$ \\
\hline $\begin{array}{l}\text { ACC (Type A) } \\
\text { Bangladesh }\end{array}$ & US\$0.37 & $1: 127,369$ & Attack dog & $146^{\text {th }}(26)$ \\
\hline $\begin{array}{l}\text { NAB (Type A) } \\
\text { Pakistan }\end{array}$ & US $\$ 0.11$ & $1: 461,442$ & Attack dog & $124^{\text {th }}(31)$ \\
\hline
\end{tabular}

Sources: Quah (2017, p. 65) and Transparency International (2021, pp. 2-3).

Table 6.

Comparing the roles of ACAs in eight Asian countries/regions 
PAP

24,2

without succumbing to the temptation of using these ACAs as attack dogs or paper tigers (Quah, 2021, p. 20).

Conversely, the plunder wrecked by corrupt political leaders in Indonesia, Malaysia, the Philippines, South Korea and Taiwan, to mention only five examples, confirms that such leaders would perpetuate the cycle of failure to further their own kleptocratic interests with impunity at the expense of their citizens and countries unless they are stopped. In the final analysis, the cycle of failure in combating corruption in Asian countries can only be broken if and when their citizens abhor corrupt leaders and elect honest and competent political leaders who would use ACAs as independent watchdogs instead of abusing the public trust by using ACAs as attack dogs or paper tigers.

\section{References}

Ahmed, B. (2006), Combating Corruption: The Role of the Bureau of Anti-Corruption (BAC) in Bangladesh, Master's Thesis, Programme in Asian Studies, Centre for East and Southeast Asian Studies, Lund University, Lund.

Alim, M.A. (2005), "Bangladesh", in Rodriguez, D., Waite, G. and Wolfe, T. (Eds), Global Corruption Report 2005, Pluto Press, London, pp. 103-105.

Aquino, B.A. (1999), Politics of Plunder: The Philippines Under Marcos, 2nd ed., National College of Public Administration and Governance, University of the Philippines, Quezon City.

Batalla, E.V.C. (2001), "De-institutionalizing corruption in the Philippines", in Pedro, A.C. (Ed.), Combating Corruption in East Asia, Yuchengco Center for East Asia, De La Salle University, Manila, pp. 41-78.

Batalla, E.V.C. (2015), "Treading the straight and righteous path: curbing corruption in the Philippines", Asian Education and Development Studies, Vol. 4 No. 1, pp. 51-75.

BBC News (2018), "Park Geun-hye: South Korea's ex-leader jailed for 24 years", 6 April.

Begum, T. and Sakib, N.H. (2010), "Combating corruption in Bangladesh: role of the Anti-Corruption Commission", in Hasanuzzaman, A.M. and Alam, S. (Eds), Political Management in Bangladesh, A.H. Development Publishing House, Dhaka, pp. 249-259.

Ben-Ghiat, R. (2020), Strongmen: How they rise, Why they succeed, How they fall, Profile Books, London.

CBC News (2008), "Imelda Marcos acquitted after 17-year trial", 10 March.

Central Bureau of Investigation (CBI) (2010), Annual Report 2009, CBI, New Delhi.

Chêne, M. (2008), "Overview of corruption in Pakistan", U4 Expert Answer, 8 August, pp. 1-13.

Chishti, S. (Ed.), (2009), India's Elected, Our MPs: A Report Card, 14 ${ }^{\text {th }}$ Lok Sabha, 2004-09, Indian Express, New Delhi.

Co, E.E.A., Lim, M., Lao, M.E.J. and Juan, L.J. (2007), Minimizing Corruption: Philippine Democracy Assessment, Friedrich Ebert Stiftung Philippine Office, Pasig City.

Colvin, R. and Bhattacharya, S. (2013), "A 'Caged Parrot' - Supreme Court describes CBI”, Reuters, 10 May.

Crisis Group (2010), “Reforming Pakistan's criminal justice system”, Asia Report, No. 196, Islamabad and Brussels, pp. 1-38.

Gill, S.S. (1998), The Pathology of Corruption, HarperCollins Publishers India, New Delhi.

GMA News.TV (2007), "Survey: Arroyo most corrupt, Aquino cleanest of 5 prexies", 11 December.

Hodess, R. (2004), "Introduction”, in Hodess, R., Inowlocki, T., Rodriguez, D. and Wolfe, T. (Eds), Global Corruption Report 2004, Chapter 1, Pluto Press, London, pp. 11-18.

Iftekharuzzaman (2019), "Anti-Corruption Commission: how can it be truly effective?", The Daily Star, 15 February. 
Jones, D.S. (2020), "1MDB corruption scandal in Malaysia: a study of failings in control and accountability", Public Administration and Policy, Vol. 23 No. 1, pp. 59-72.

Kanyakumari, D. (2020), "Former Malaysia PM Najib Razak sentenced to 12 years in jail following guilty verdict in 1MDB trial", Channel News Asia, 28 July.

Loveard, K. (1999), Suharto: Indonesia's Last Sultan, Horizon Books, Singapore.

Marcelo, S.V. (2005), Combating Corruption in the Philippines: Are we Plundering our Chances or Doing it Better?, National College of Public Administration and Governance, University of the Philippines, Working Paper Series No. 2, Quezon City.

Meagher, P. and Voland, C. (2006), “Anti-corruption agencies (ACAs): Office of Democracy and Governance anti-corruption program brief", United States Agency for International Development, Washington, DC.

Office of the Ombudsman (OMB) (2015), Annual Report 2014, OMB, Quezon City.

Oyamada, E. (2005), "President Gloria Macapagal-Arroyo's anti-corruption strategy in the Philippines: an evaluation", Asian Journal of Political Science, Vol. 13 No. 1, pp. 81-107.

Punch, M. (2009), Police Corruption: Deviance, Accountability and Reform in Policing, Routledge, London.

Quah, J.S.T. (1982), "Bureaucratic corruption in the ASEAN countries: a comparative analysis of their anti-corruption strategies", Journal of Southeast Asian Studies, Vol. 13 No. 1, pp. 153-177.

Quah, J.S.T. (2011), Curbing Corruption in Asian Countries: An Impossible Dream?, Emerald Group Publishing, Bingley.

Quah, J.S.T. (2017), Combating Asian Corruption: Enhancing the Effectiveness of Anti-Corruption Agencies, Carey School of Law, University of Maryland, Baltimore, MD.

Quah, J.S.T. (2020), "Taiwan should abandon its irrational anti-corruption strategy", Taiwan Insight, 30 October, available at: https://taiwaninsight.org/2020/10/30/taiwan-should-abandon-itsirrational-anti-corruption-strategy/ (accessed 25 May 2021).

Quah, J.S.T. (2021), "Best practices for combating corruption: learning from Singapore and Hong Kong”, in Tummala, K.K. (Ed.), Corruption in the Private Sector: An International Perspective, Chapter 2, Emerald Publishing, Bingley, pp. 7-22.

Quimson, G. (2006), National Integrity Systems Transparency International Country Study Report Philippines 2006, Transparency International, Berlin.

Ramesh, R. (2016), "1MDB: the inside story of the world's biggest financial scandal", The Guardian, 28 July.

Rotberg, R.I. (2009), "Leadership alters corrupt behavior", in Rotberg, R.I. (Ed.), Corruption, Global Security, and World Order, Chapter 13, Brookings Institution Press, Washington, DC, pp. 341-358.

Schlesinger, L.A. and Heskett, J.L. (1991), "Breaking the cycle of failure in services", MIT Sloan Management Review, Vol. 32 No. 3, pp. 17-28.

Shah, A. (2001), "South Asia", in Hodess, R. (Ed.), Global Corruption Report 2001, Transparency International, Berlin, pp. 39-52.

Singh, J. (1999), Outside CBI, Gyan Publishing House, New Delhi.

South China Morning Post (2007), “A job for Estrada would help Arroyo keep hers”, 29 October, p. 14.

Straits Times (2020), "South Korea's ex-president Lee Myung-bak goes back to prison”, 2 November.

Tepperman, J. (2016), The Fix: How Nations Survive and Thrive in a World in Decline, Tim Duggan Books, New York, NY.

Transparency International (2021), Corruption Perceptions Index 2020, Transparency International, Berlin.

Transparency International Pakistan (TIP) (2014), Pakistan National Integrity System Country Report 2014, TIP, Karachi.
Corruption in Asian countries 
PAP

24,2

138

Transparency International Pakistan (TIP) (2017), Anti-Corruption Agencies Strengthening Initiative Assessment of Pakistan National Accountability Bureau, TIP, Karachi.

Vittal, N. (2012), Ending Corruption? How to Clean up India, Penguin Books India, New Delhi.

Waseem, M. (2002), "Corruption, violence and criminalisation of politics in Pakistan", in de Silva, K.M., Peiris, G.H. and de A Samarasinghe, S.W.R. (Eds), Corruption in South Asia - India, Pakistan and Sri Lanka, Chapter 4, International Centre for Ethnic Studies, Kandy, pp. 139-188.

World Bank (2020), "Worldwide Governance Indicators 2019”, Washington, DC, available at: https:// info.worldbank.org/governance/wgi/ (accessed 16 June 2021).

Wright, T. and Hope, B. (2019), Billion Dollar Whale: The Man Who Fooled Wall Street, Hollywood, and the World, Hachette Books, New York, NY.

Zaman, I., Rahman, S. and Alim, A. (2006), "Bangladesh”, in Kotalik, J. and Rodriguez, D. (Eds), Global Corruption Report 2006, Pluto Press, London, pp. 126-130.

\section{About the author}

Jon S.T. Quah is a retired Professor of Political Science at the National University of Singapore and an anti-corruption consultant based in Singapore. He has published extensively on corruption and governance in Asian countries. His recent books include: Combating Asian Corruption: Enhancing the Effectiveness of Anti-Corruption Agencies (2017); Hunting the Corrupt "Tigers" and "Flies" in China (2015); Different Paths to Curbing Corruption (2013); and Curbing Corruption in Asian Countries: An Impossible Dream? (2011). Jon S.T. Quah can be contacted at: jonstquah@gmail.com

For instructions on how to order reprints of this article, please visit our website: www.emeraldgrouppublishing.com/licensing/reprints.htm Or contact us for further details: permissions@emeraldinsight.com 